\title{
The economics of deflation in the euro area: a critique of fiscal austerity
}

\author{
Giuseppe Mastromatteo* \\ Catholic University of Milan, Italy \\ Sergio Rossi ${ }^{\star}$ \\ University of Fribourg, Switzerland
}

\begin{abstract}
This paper points out that the roots of the euro-area crisis are to be found in the loss of monetary sovereignty and an unsustainable credit-led economic growth in a variety of 'peripheral' countries. It addresses the negative consequences of fiscal austerity in the euro-area crisis framework, in particular regarding the distribution of income and the economic and financial relations between 'core' and 'peripheral' countries within the euro area. The paper also argues that the deflationary effects of the conventional policy reaction to the euro-area crisis will aggravate recession over the medium-to-long run in that area, owing to their negative impact on demand in the product markets across the whole European Union, whose competitiveness will suffer under the very measures that are supposed to enhance it in the global economy.
\end{abstract}

Keywords: austerity, deflation, euro area

JEL codes: $E 61, E 62, E 63$

\section{INTRODUCTION}

This paper focuses on so-called 'fiscal consolidation' measures adopted in a number of euro-area countries to address the consequences, rather than the causes, of the crisis that erupted at the end of 2009 in Greece and then rapidly spread across Euroland. It explains that these measures induce a deflationary pressure, which aggravates the situation in the euro area as a whole. In so doing, this paper provides a negative assessment of austerity policies implemented across a number of euro-area countries at the time of writing. It also shows that these policies cannot dispose of the deep causes that originated the euro-area crisis. Section 2 argues that the roots of the euro-area crisis are to be found in the loss of monetary sovereignty as well as in an unsustainable creditled economic growth within a variety of 'peripheral' member countries. Section 3 addresses the negative effects of fiscal austerity in the euro-area crisis framework. It shows that austerity measures exert a negative impact on the (personal and functional) distribution of income and on the economic and financial relations between 'core' and 'peripheral' countries in the euro area. Section 4 explains that the deflationary effects of the conventional policy reaction to the euro-area crisis are going to aggravate recession over the medium-to-long run in that area, owing to their negative impact on total applies.

The authors thank an anonymous referee for his constructive remarks. The usual disclaimer 
demand in the markets for produced goods and services across the whole European Union, whose competitiveness is likely to suffer under the measures that are supposed to enhance it in the global economy. Section 5 concludes briefly.

\section{THE MONETARY-STRUCTURAL FACTORS BEHIND THE EURO-AREA CRISIS}

The euro-area crisis has revived the debate about the theory of optimum currency areas (OCAs) (Mundell 1961) with regard to the level of both economic and political integration required in order to provide an efficient macroeconomic reaction to asymmetric shocks that may hit euroland, which is clearly not an OCA to date (see Eichengreen 1990; Bayoumi and Eichengreen 1997). In particular, workers' mobility between the different member countries of the European Monetary Union (EMU) has always been very low - compared for instance to the United States - and the very low number of fiscal transfers between these countries does not provide a powerful enough instrument to represent an efficient adjustment mechanism in cases of asymmetric shocks hitting the EMU. Further, it is well known that "[f]iscal and monetary policies must go hand in hand, and if there is to be an "optimum policy mix," they should have the same domain. There should be a treasury, empowered to tax and spend, opposite each central bank' (Kenen 1969, pp. 45-46). ${ }^{1}$ Indeed, a federal tax system provides in any case an automatic stabilizer, and the capacity of the federal budget to protect against asymmetric shocks increases, if it allows for countercyclical fiscal transfers between the member states of the federation.

It is also well known, and widely agreed, that a federal fiscal authority can obtain better results in terms of welfare within the federation than its different member states, owing to its capacity to redistribute explicitly the intertemporal burden of taxes and subsidies across the whole federation (Sala-i-Martín and Sachs 1992). More generally speaking, an OCA implies a political cohesion that the EMU does not have, to date, but would require; in particular, to overcome the most difficult periods of the stillongoing euro-area crisis.

Further, fixed-exchange-rate regimes, and particularly a single-currency area, induce an implicit moral hazard owing to excessive (implicit or explicit) guarantees (Eichengreen and Hausmann 1999): in these regimes, the government has to make sure that there are no possibilities of abandoning the fixed-exchange-rate regime, thereby providing to private sector agents an insurance against exchange-rate risks. Hence, private sector agents, and especially financial institutions, do not need to hedge against these risks, which, within a single-currency area (like the EMU) also include sovereign debt risks (see Rossi and Dafflon 2012).

In fact, the implicit guarantee that no EMU member country will abandon the euro has not so far been the result of a true integration process between euro-area countries. Indeed, it is plain that these countries have been showing a high degree of economic divergence since they abandoned their national currencies to enter the euro area (Rossi 2007). As Bagnai (2013, p. 10) points out, from January 2003 to December 2007 - that is, before the global financial crisis broke out - the interest-rate spread on government debt within the euro area with respect to the German 'Bund' came close to zero, although 'four years after the inception of the euro, loans to the private

1. Bibow (2013b) suggests therefore the setting up of a Euro Treasury opposite the European Central Bank. 
sector provided still a lot of interesting arbitrage opportunities for the "core" [creditor countries]', particularly with respect to business loans in Greece, Portugal and Ireland, and as regards mortgage loans in Spain.

Moreover, despite a single monetary policy, inflation rates have also diverged across the EMU since the adoption of the European single currency: from 1999 to 2007, the rate of inflation in Germany has always been lower than in the rest of the euro area (apart from Finland in some years). As Cesaratto and Stirati (2011) explained, this phenomenon is connected, historically, with the decision by the German establishment to adopt an export-led regime for economic growth based on prolonged wage repression in order to reduce unit labour costs in real terms and thereby improve German competitiveness against all other EMU countries (Bibow 2013a; Rossi 2013). Now, persistent inflation differentials in a single-currency area elicit persistent trade deficits in those countries where the inflation rate is higher than the area-wide average rate of inflation, owing to the deterioration in their price competitiveness, which also causes an accumulation of foreign debt for them (Fleming 1971).

Vernengo and Pérez-Caldentey (2012) elaborate on this analysis, to argue that monetary union and financial deregulation have allowed 'core' countries within the euro area to exploit their export-led growth strategies as 'beggar-thy-neighbour policies': the huge savings formed in these countries as a result of their net exports have been lent to deficit countries, where the lending rates of interest were higher. This made it possible for the latter countries to finance their current-account deficits before the eruption of the global financial crisis. This debt-led economic growth in 'peripheral' countries has supported aggregate demand in these countries, thus allowing 'core' countries (first and foremost Germany) to record persistent trade surpluses until their external imbalances became unsustainable for the weakest countries in the aftermath of the global financial crisis that erupted in 2008 following the collapse of Lehman Brothers (Rossi 2013; 2015).

This explanation supports the view that the euro-area crisis is essentially a balanceof-payments crisis; that is to say, an external-debt-sustainability crisis (Bagnai 2013, p. 12). This contrasts with the more orthodox explanation of the euro-area crisis as a sovereign-debt crisis, although an increasing number of orthodox economists recognize that the sovereign-debt crisis is deeply intertwined with the macroeconomic imbalances across the euro area (Lane 2012, p. 50). These explanations may seem to be compatible at the theoretical level, as illustrated by the theory of the so-called 'twin deficits' (that is, the fiscal deficit and the ensuing trade deficit, as explained in the Mundell-Fleming model): an expansionary fiscal policy gives rise to a public deficit, which induces an increase in the domestic rate of interest, thereby attracting foreign capital and eventually raising the current-account deficit. In fact, as Bagnai (2013, p. 12) points out, during the period that runs from the euro changeover (1999) to the eruption of the euro-area crisis, the interest-rate spread on government bonds has been reduced close to zero within that area. This shows that fiscal policies in the EMU member countries have not been so expansionary as to induce an increase in the rates of interest on 'profligate' government bonds. At the same time, the persistence of positive spreads in some segments of the financial market shows that surplus countries had an interest in lending their net savings to private sector agents in 'peripheral' countries (Rossi and Dafflon 2012).

As a matter of fact, empirical evidence about the existence of 'twin deficits' shows that the correlation between fiscal deficits and trade deficits is rather weak: the coefficients lie between 0.1 and 0.3 , meaning that a fiscal deficit of 1 euro is associated with a trade deficit of between 10 and 30 cents (see Chinn and Prasad 2003; Bagnai 2006; Bartolini and Lahiri 2006). Indeed, the empirical analysis carried out by Bagnai (2013) confirms 
that 'peripheral' countries within the euro area have recorded a huge increase in private sector deficits (that is, a reduction in net private savings), together with a reduction in public deficits and an increasing deficit of their current account (see Rossi 2013). All this suggests that the financial troubles of these countries have been the result of an accumulation of private debt (rather than public debt) to a variety of foreign creditors (mainly financial institutions). Hence, the euro-area crisis has not been generated by 'fiscal profligacy' by the general government sector of different countries but by an excessive borrowing by the private sector of many 'peripheral' countries. This means also that financial institutions in 'core' countries have been lending too much at too low interest rates, in order for these institutions to 'recycle' domestic savings and earn huge profits via their lending practices to residents in deficit countries across the euro area.

The loss of monetary sovereignty by EMU member countries is a further factor of crisis, as it not only disposes of interest-rate policy as an important economic policy tool, but it also inhibits any exchange-rate competitive devaluation of the domestic currency (since it has been replaced by the euro). In a single-currency area the only possible adjustment to curb the loss of a country's competitiveness is therefore wage and fiscal deflation. As a result, the adoption of the euro imposes 'fiscal discipline' to EMU member countries, as they can no longer resort to currency devaluation in order to avoid those structural reforms (particularly with regard to the labour market) that the economics profession views as necessary for improving the competitiveness of any weak countries (see Huerta de Soto 2012). Indeed, as Krugman (2011) points out, "the euro will stand or fall on the ability of those countries that had rapidly rising costs and prices between 2000 and 2007 to get those costs and prices back in line. At this point the de facto strategy of European leaders is to require that they do this via deflation. And that will not work'. As is well known, although this is largely underestimated, deflation has a strong negative impact on the sustainability of both public and private debt (see Fisher 1933). Those countries that need to improve their competitiveness must have an inflation rate lower than their main competitors, but a rate of inflation close to (or below) zero aggravates public debt sustainability (Darvas 2013). The inflation target 'close to but below 2 per cent' of the European Central Bank (ECB) is therefore problematic in that regard: the more a weak country comes close to deflation, the higher is the primary surplus as a percentage of GDP that its public sector must record, in order to avoid a 'spiral of debt explosion'. This means that countries like Italy and Spain should have a primary surplus higher than 5 per cent of their GDP for many years, to avoid putting the sustainability of their public debt at stake. $^{2}$

\section{THE NEGATIVE MACROECONOMIC CONSEQUENCES OF FISCAL CONSOLIDATION}

Mainstream economists are aware that structural imbalances across the EMU should be reduced, but consider that the adjustment burden of current accounts has to be borne by debtor countries only (see Brancaccio and Passarella 2012, p. 69). These countries must therefore adopt austerity policies with regard to public spending and

2. As Darvas (2013, p. 5) observes, however, '[o]ver the last 50 years, no OECD country (except Norway, thanks to oil surpluses) has sustained a primary surplus above 5 percent of GDP'. 
private sector wages, in particular by liberalizing their labour and product markets. On one hand, fiscal austerity will reduce imports, hence improving the current-account balance, as a result of its impact on domestic demand. On the other hand, market liberalization will allow the reduction of wage levels, hence prices, which will then improve the country's competitiveness and thereby increase its commercial exports. Eventually, these interventions will balance the current accounts of debtor countries, thus reducing their risks perception by market participants.

In fact, this (orthodox) understanding of the rebalancing mechanism ignores a number of critical issues. Let us summarize them briefly.

(a) Generally speaking, employment levels essentially depend on global demand rather than on labour market flexibility. Flexible job agreements, increased job insecurity, and freedom of dismissal give rise to senior workers' substitution by lower-paid wage earners, thereby reducing the firms' total wage bill and therefore also the purchasing power of the whole set of working households.

(b) Fiscal austerity and labour market flexibility lead to an international conflict within the euro area that has recessionary effects across Europe. Austerity policies reduce global demand and disposable income, thereby aggravating the crisis and reducing the possibility of repaying (private and public) debt, thus strengthening the perception by financial market participants that some euro-area countries might leave it sooner or later.

(c) The race to the bottom induced by the reduction of wage earners' compensation in trade deficit countries gives rise to a negative spiral across the euro area, where the purchasing power of wage earners is progressively and generally reduced, as shown by the role of Germany in the competition to reduce relative wages (Brancaccio and Passarella 2012, p. 69). In this framework, debtor countries can increase their degree of competitiveness only temporarily, and their financial problems will in fact persist in an economic-growth regime based on 'competitive wage deflation'.

Indeed, the euro-area crisis could be solved by addressing its imbalances with balanced mechanisms that support weak countries and promote sustainable economic growth (see Rossi 2012; Barba and De Vivo 2013). According to the European Commission's estimates, the EMU GDP in 2013 was below its 2007 level by roughly 2 percentage points, and the number of unemployed people in 2013 was more than 7.5 million above its 2007 level. This contrasts with the situation in the United States, where economic policy has been less austere than in the European Union, so that the US GDP level in 2013 was nearly 6 percentage points higher than its pre-crisis level.

This US-EU gap is a result of the strong disagreement between (orthodox) neoclassical and (heterodox) Keynesian economic theories and policies (Cozzi 2013). A number of mainstream authors have been arguing that a well-designed austerity programme, which implies spending cuts and a balanced budget for the general government sector, will not only avoid depression but also stimulate the economy hence the label 'expansionary austerity' (see, for instance, Giavazzi and Pagano 1990; 1996; Alesina and Perotti 1995; 1997; Alesina and Ardagna 1998; 2010). The risk of a 'double dip', however, at the EU level, after the first wave of the global crisis in 2008-2010, should have led EU leaders to adopt a more careful attitude as regards austerity policies in light of the fragility of the business cycle across the whole euro area (and beyond it) at the time of writing. 
Indeed, economic history shows that austerity policies give rise to perverse effects when

(a) they are carried out simultaneously in a number of countries that are relevant for the performance of the global economy,

(b) the international framework is not characterized by strong economic growth, and/or

(c) the financial situation is problematic or out of control in several countries.

When a number of relevant countries adopt austerity policies simultaneously, there are generally two risks. The first is the ' 1937 risk', to wit, the risk of believing that a recession is over, whilst the opposite is true. If decision-makers in all these countries consider that the peak of the crisis is past and that the economy has entered a recovery, and therefore accelerate the process of fiscal consolidation, they thus depress aggregate demand and induce a series of disappointing effects with regard to their expectations. If so, then austerity programmes are strengthened, leading to a perverse spiral that hurts an increasing number of people without any possible solution along these lines. The second risk aggravates the former: if each country carries out its austerity policy supposing that, in the rest of the world, both income and aggregate demand are not reduced, then global demand diminishes, inducing the risk of a global crisis. In this framework, interest rates increase for debtor countries (hence also for those countries that are closely linked with them on economic and financial grounds), becoming unsustainable as they exceed those advantages that are (supposed to be) elicited by austerity programmes. The international framework is therefore contingent on the different 'interconnections' between countries that pertain to the global economy, and economic growth depends also on the dynamics of foreign trade, exchange rates, interest rates for loans in different denominations, and the prices of raw materials (particularly oil), all of which have an impact on production costs. To be sure, deflationary policies in a fragile international framework often end up destabilizing the weakest economic agents across the global economy.

Furthermore, financial crises are different from 'canonical' recessions, owing to the velocity that affects the transmission mechanism of shocks in such a crisis framework. This is in open contrast to the slow pace of political decisions, better suited for a recession than a financial crisis. The consequences of this discrepancy may be dramatic: what could be solved at time $t$, for instance a financial crisis in a single country, may become a global crisis if it is addressed too late, when markets are affected by widespread panic as well as distrust among its participants. As a result, it becomes more difficult to re-establish a reasonable level of trust, when economic agents believe that current or future economic policies will reduce total demand rather than support it over time.

Also, the available empirical evidence about the welcome results of austerity policies is affected by methodological criticisms (Blanchard and Leigh 2013; Herndon et al. 2014). Once these critiques are integrated into the analysis, this shows that, with regard to the austerity programmes carried out by 15 advanced economies in the 1980-2009 period, as observed by the International Monetary Fund (2010, p. 94), '[f]iscal consolidation typically has a contractionary effect on output'. This is so because '[a] fiscal consolidation equal to 1 percent of GDP typically reduces GDP by about 0.5 percent within two years and raises the unemployment rate by about 0.3 percentage point' (ibid.). The magnitude of these effects is even stronger, as recognized by Blanchard and Leigh (2013), when an array of countries in deep recession adopt fiscal austerity simultaneously. Also, one must remember that fiscal consolidation policies have usually been mitigated by significant reductions in policy rates of interest and, more 
importantly, by significant exchange-rate devaluations, both of which are impossible for the EMU member countries, as they have surrendered their monetary sovereignty to the ECB (which is reluctant to devalue the exchange rate of the euro and reduced its policy rates of interest 'too little and too late' with regard to the dramatic situation across the euro area).

On the whole, the idea of 'expansionary austerity' has its only theoretical support in the argument that a countercyclical fiscal policy should be rejected in order to avoid the risk of unsustainable fiscal deficits and excessive public debt (as in the Maastricht Treaty for the EMU). In fact, however, the increase in both public deficits and debt across the euro area in the aftermath of the crisis has been a result rather than a cause of that crisis. As a matter of fact, the reduction in national income and the fiscal deficit generated by lower tax receipts and higher social-security expenditure as a result of the crisis have induced a significant increase in both public deficits and debt across the euro area. As Nuti (2013) points out, this is especially so when the fiscal multiplier is higher than 1 (see for instance Blanchard and Leigh 2013, who consider that the fiscal multiplier lies between 0.9 and 1.7). ${ }^{3}$ Now, a number of economists in the mainstream acknowledge that fiscal consolidation may aggravate recession over the short run, but argue that, over the long run, the benefits of austerity are more relevant than its costs. For instance, according to the European Central Bank (2012, p. 85), '[w] hile fiscal consolidation may adversely affect growth in the short term, the medium to long-term effects are favourable and more than compensate any short-term shortfall'. ${ }^{4}$ To be true, as pointed out by Cozzi $(2013$, p. 141), this alleged virtuous circle needs 'more than ten years' to be observed, according to the simulation conducted by the European Central Bank (2012, p. 84). If so, then the horizon is too long for the population to support austerity policy when the economic system is in a deep recession, and it does not exclude the possibility that the government will change its policy stance later on. Indeed, the European Central Bank (2012, p. 85) seems to be aware of the theoretical weaknesses of its argument, when it notes that '[o]verall, also given the very large size of the public sector in many [EMU member] countries, the bulk of fiscal adjustment should be borne on the expenditure side, while avoiding cuts in productive government spending'. The problem, however, is that the ECB does not define what 'productive government spending' means, so one is left with the impression that its arguments are ideologically oriented rather than being conceptually sound with respect to economic analysis.

As regards financial market participants, Nuti (2012, pp. 143-144) points out that they display schizophrenic behaviour when confronted with fiscal consolidation: their initial euphoria is followed by a fear of recession. If so, then highly indebted governments are not in a position to continue borrowing on financial markets, because even the most favourable decisions to limit their borrowing risks are pondered by potential lenders as aggravating the recession. In such a situation, fiscal consolidation may induce a vicious circle that in the long run increases the unsustainability of public debt rather than reducing it.

3. Other authors estimate the fiscal multiplier to be between 1.6 and 2.6 (Batini et al. 2012), but in a 'liquidity trap' (that is, when the rate of interest is at the zero lower bound) Christiano et al. (2011) consider that the fiscal multiplier can be as high as 3.2.

4. See also Cottarelli and Jaramillo (2012, p. 3), who argue notably that '[r]eforms in goods, service, and labor markets that improve economic efficiency will boost potential growth, in turn serving as important tools in the fiscal adjustment process'. 


\section{THE NEGATIVE DISTRIBUTIONAL EFFECTS OF DEFLATIONARY POLICIES IN THE EURO AREA}

Fiscal consolidation also has a number of relevant distributional effects both within and between euro-area countries. Ball et al. (2013) provide empirical evidence that shows a persistent and significant increase in income inequality as a result of fiscal consolidation in a sample of 17 OECD countries, which led to a reduction of the wage share as well as an increase in unemployment rates over the 1978-2009 period. These effects are bigger, in particular, when fiscal consolidation occurs in a framework where income and wealth inequality is already high and rising, like in the euro area, as a result of the globalization and financialization of economic activities (Hein 2013). As a matter of fact, within a framework that was unbalanced in the first place, fiscal consolidation is increasing the macroeconomic imbalances across the euro area, so much so that its peripheral member countries are those in which austerity programmes are the most severe.

Jenkins et al. (2012) confirm this empirical evidence by analysing the short-run impact on income distribution of the global financial crisis that erupted in 2008. They investigated in particular average household income, income inequality, and the poverty rates in six advanced countries (Germany, Ireland, Italy, Sweden, the United Kingdom and the United States) up to 2010. Their results show that the impact of the crisis has been different across these countries, and its negative effects could be contained owing to the lessons that policy-makers have drawn from the Great Depression in the 1930s. A number of national governments within the EU have thus resorted to their social security network in order to avoid social turmoil, even though the most problematic peripheral countries were obliged to adopt severe austerity programmes in the aftermath of the euro-area crisis.

As Navicke et al. (2013) show, the difficult macroeconomic conditions and the negative consequences of tax and pension-scheme reforms, as a result of fiscal consolidation, are increasing the risk of poverty, in particular for the most fragile categories of individuals (like children and young adults), notably in Greece, Lithuania and Spain. These problems also affect the elderly in an increasing number of countries where pension schemes are being reformed in order to reduce their expenditures.

It does not come as a surprise, therefore, that austerity policies have recessionary effects and thereby reduce firms' profits, thus increasing their fragility. As a result, the financial stability of the business sector as a whole is weakened, inducing a significant reduction of bank credit to finance production activities. ${ }^{5}$ The reduction in firms' investment has a negative impact on economic growth, thereby aggravating the recession that has been affecting the EMU, particularly its peripheral countries, since the euro-area crisis erupted. As a matter of fact, since that crisis began, the debt-to-networth ratio of big companies in Italy, Spain, France and Portugal has been widely increased, especially for smaller businesses, which not only increased their indebtedness, but also sold their most liquid assets, in order to finance their activities. All in all,

5. The reduction of bank credit volumes is the result of both a supply- and a demand-side phenomenon. On the supply side, banks are reluctant to increase their lending to firms, as their balance sheets are fragile as a result of the economic situation and its perspectives over the short run. On the demand side, businesses are unwilling to increase their borrowing, as their investment projects are hindered by the same economic situation and perspectives. As Artus (2014) notes, a 'quantitative easing' by the ECB is likely to be fully ineffective in such a framework. 
this further aggravated the private debt problem across the euro area, as a result of fiscal consolidation measures.

In fact, however, austerity polices and credit restrictions by banks do not affect all firms in the same proportion. Rather, they increase the conflicts between big corporations (usually export-oriented and located in 'core' EMU countries) and smaller firms (largely domestically oriented and located in 'peripheral' euro-area countries). Indeed, the increase in unemployment rates and the resulting cuts in wages induced by austerity policies allow transnational corporations to reduce their production costs, thereby improving their global competitiveness, hence increasing their profits. In addition, big corporations may influence government policies using their threat to locate (a part of) their activities in a more convenient jurisdiction. By contrast, smaller firms in domestic markets suffer most from fiscal consolidation, as the latter reduces the demand for their products, thereby reducing their profits and increasing the number of failures. Also, a credit crunch does not affect big companies as much as it affects smaller firms, for many reasons. First, large transnational corporations may raise funds on the financial market, bypassing the banking channel (see Gambacorta and Marques-Ibanez 2011). Second, bank credit is cheaper for these corporations, as they are supposed to be too big to fail. Third, in light of their higher profits with respect to those of smaller firms, they are in a position to better self-finance their investment projects, even though in a recession the propensity to invest declines. The banks' willingness to provide credit to firms and their rates of interest in that regard are also different between weak and strong economies: the latter can therefore support their domestic business sector better, hence improving firms' competitiveness, owing to the lower financing costs for the local banking sector than in debtor countries. This is especially so when the public sector of a strong economy is in a better financial situation than it is the case in a debtor country, when it is able to support unemployed people and help them to find new job opportunities.

These features can increase macroeconomic imbalances between rich and poor countries in the euro area: its periphery would thereby become a European colony with a very low level of national income and an increasing desertification of production activities.

In fact, the euro area needs a 'recycling mechanism' through which the macroeconomic saving formed in net exporting countries is automatically lent to net importing countries in order for the latter countries to finance their current-account deficits (see Halevi and Varoufakis 2003). This is not what has occured to date, as the increasing competitiveness gap between 'core' and 'peripheral' euro-area countries is supported by mercantilist policy-oriented arguments that reject the establishment of a transfer union and a true social and economic integration between these countries (Barba and De Vivo 2013). ${ }^{6}$ As a matter of fact, austerity policies have abundantly reduced trade deficits of 'peripheral' euro-area countries whilst its 'core' countries (particularly

6. Recently this argument has also been raised by Draghi (2014), who explained that monetary unions need permanent fiscal transfers in order to be viable over the long run: '[i]n all national economies, permanent transfers take place from richer to poorer regions; from more densely populated to more sparsely populated areas; and from those better endowed with natural resources to those less endowed. This is true in the United States, where those transfers occur through the federal budget. It is true within Germany, within Italy, within Finland. Fiscal transfers, so long as they remain fair, often help cement social cohesion and protect against the temptation of secession'. In the same speech at the University of Helsinki, Draghi (ibid.) pointed out that, in the current institutional set-up of the euro area, where public (fiscal) transfers are lacking across its member countries' borders, their role has been carried out by private capital flows from rich to poor countries, until the euro-area crisis erupted at the end of 2009. There is, however, a 
Germany) have continued to record relevant current-account surpluses with respect to their GDP. However, this situation is not sound, because it induces a contraction rather than an expansion of foreign trade, owing to the recessionary impact of fiscal consolidation on domestic demand in those countries most in need of a recovery (which could be boosted if these countries exported more - rather than importing less - in order to rebalance their foreign trade).

In order to reduce public debt and deficits with respect to GDP across the euro area, its most affected countries must replace fiscal consolidation with economic growth. As an array of long-period analyses show (see Jordà et al. 2013 for a brief survey), without an appropriate fiscal capacity for the public sector, macroeconomic stabilization as well as economic growth may be impossible to attain. This is especially so in those countries that abandoned their monetary sovereignty (as it occurred in the euro area), for they cannot resort to their national central bank to monetize public debt.

Now, economic-growth policies across the euro area can be ranged in two very different camps, namely:

1. a neoliberal view, that considers that the adjustment onus must be borne by debtor countries only, through a number of painful structural reforms to increase labour market flexibility, to reduce the size of the public sector, and to reinforce banking institutions with the help of foreign direct investment in these countries; and

2. an alternative view, arguing in favour of (debt-financed) public investment in order to increase a country's competitiveness and to make its public debt sustainable over time. The so-called classical 'golden rule' of public finance, in fact, distinguishes a government's consumption (which has to be financed entirely by taxes) from public investment, which should be financed by a government's borrowing as the result of an investment that benefits several generations of taxpayers (each of which should therefore contribute to it on a 'pay-as-you-use' basis).

In a deep economic recession, in fact, the neoliberal policy stance further aggravates the situation, as it increases unemployment and thereby reduces total demand on the goods market, thus giving rise to a negative spiral that pushes the economic system into a depression. As a matter of fact, in an economic recession, particularly when the latter is deep and widespread (across a currency area), deflationary policies are problematic, for a number of reasons (Morselli 2013):

1. the increase of unemployment rates does not lead to a reduction in the wage level over the short run. Very often, the increase in structural unemployment increases downwards wage rigidity;

2. the reduction of wages has only a short-run impact on labour demand, increasing it only temporarily (substitution effect), as it reduces the latter over time owing to the reduction of consumption levels as a result of wage earners' lower compensation (income effect);

3. the profitability effect may overcome the competitiveness effect, as the reduction in real wages induces firms to increase their profitability rather than reduce the retail prices of their output on the goods market. The increase in firms' competitiveness is therefore purely theoretical; and

key difference between fiscal transfers and capital flows, as the latter imply debt that must be reimbursed and is charged with an interest payment, whereas the former is a unilateral flow and has no interest payment associated with it. 
4. the competitiveness effect strongly depends on the business cycle, as it has a limited impact on structural unemployment, and does not really occur when wage deflation is observed in a number of countries simultaneously. When the latter reduce wages and prices, eventually none of them can increase its competitiveness.

These phenomena show that deflationary policies during a widespread recession induce a higher rate of unemployment, thereby aggravating social and political conflicts rather than leading to economic growth and public debt sustainability. To obtain the latter, one needs a different economic policy stance, aiming at strengthening domestic demand and firms' competitiveness, particularly in those euro-area countries where both are lacking at the time of writing. To be successful in this regard, nevertheless, it is necessary that EMU member countries coordinate their economic policies: owing to the existing series of external constraints within the global economy, uncoordinated economic policies will be ineffective in addressing macroeconomic imbalances successfully. A coordination of these policies may indeed neutralize (at least part of) those external constraints, so that a pan-European series of policies supporting economic growth is likely to be successful.

In this framework, expansionary policies to support global demand can contribute to a rapid increase in production and employment levels, without exerting upward pressures on the general price level. Indeed, Keynesian instruments to regulate total demand could reduce involuntary unemployment, as the latter stems from a lack of demand on product markets, on condition that firms have unused productive capacity and that there is some coordination of economic policies to soften existing external constraints. In particular, a series of European investment programmes will contribute to the cessation of the negative spiral in a number of 'peripheral' countries within the euro area. The European Investment Bank could supervise (or carry out) these investment programmes, provided that its capital is increased considerably (far beyond the $€ 10$ billion that were granted in 2012 for stimulating growth and employment) and that its governance is improved to increase the velocity of the decision-making process with regard to its disbursements. ${ }^{7}$

Furthermore, promoting economic growth should become the first priority of each euro-area member country, through the adoption of more appropriate expansionary fiscal policies and an increase in real wages in all those ('core') EMU countries where this is possible, in light of their macroeconomic performance. In addition, and urgently, there should be a correct assessment of banking problems and recapitalizations, to support bank credit for production activities across the euro area (Darvas 2013 , p. 11). These banking problems cannot eventually be solved unless domestic demand in the relevant countries increases as a result of public spending in a number of areas that support the middle class - where many households entered into debt in order to keep their standard of living as a result of a stagnation in their real wages. This is most importantly the case in Germany, whose banking sector still records a mountain of 'illiquid' assets and whose population includes 24.5 per cent of workers

7. The so-called ' $€ 315$ billion investment plan' announced by the President of the European Commission on 26 November 2014 is not up to the task, as its expected leverage effect is a figment of the imagination. It is indeed unlikely that, by providing $€ 5$ billion through the European Investment Bank, and with $€ 8$ billion reallocated in the budget of the European Commission (which may become $€ 16$ billion in the form of an EU-wide public guarantee), private investment will be induced for a total amount close to $€ 300$ billion over the 2015-2017 period. To be sure, the investment multiplier should be around 15 , a magnitude that has never been observed historically, particularly in the aftermath of a major economic or financial crisis. See Juncker (2014). 
earning less than 60 per cent of the national median wage (Watt 2013). Indeed, wageearners' compensation in Germany must be increased according to the productivity improvements in the relevant sector and above the ECB's inflation target - which should also be increased to 3 or 4 per cent (see Blanchard et al. 2010). This will contribute to the reduction of Germany's trade surplus through higher German imports of other euro-area countries' products. The rebalancing of intra-euro-area foreign trade must indeed allow for an expansion, rather than a contraction, of economic activity across that area, as pointed out by the US Department of the Treasury (2013, p. 3):

Within the euro area, countries with large and persistent surpluses need to take action to boost domestic demand growth and shrink their surpluses. Germany has maintained a large current account surplus throughout the euro area financial crisis, and in 2012, Germany's nominal current account surplus was larger than that of China. Germany's anemic pace of domestic demand growth and dependence on exports have hampered rebalancing at a time when many other euro-area countries have been under severe pressure to curb demand and compress imports in order to promote adjustment. The net result has been a deflationary bias for the euro area, as well as for the world economy.

To be sure, as the US Department of the Treasury (2013, p. 3) points out, '[s]tronger domestic demand growth in surplus European economies, particularly in Germany, would help to facilitate a durable rebalancing of imbalances in the euro area'. This is also required by the prevention and correction of macroeconomic imbalances that the European Commission put into force on 13 December 2011 under the heading of the so-called 'six pack' (European Commission 2011): since 2007, the 3-year moving average of the current-account surplus of Germany lies above 6 per cent of its GDP, a ratio that the 'six pack' establishes as the upper limit, beyond which the country must necessarily rebalance its foreign trade.

\section{CONCLUSION}

Wage and fiscal deflation cannot solve the euro-area crisis. It is now widely recognized that the 'scientific' support for austerity programmes has major flaws on both empirical and methodological grounds. Indeed, the International Monetary Fund is also aware that fiscal consolidation - notably with regard to drastically reducing public spending on health and social policies - does not reduce the public-deficit-to-GDP ratio of a recession-hit country. On the contrary, this ratio increases dramatically over time, inducing a further round of expenditure cuts by the public sector in a never-ending, deflationary spiral in which the population suffers increasingly and without any hopes for a better future. This empirical evidence is plain. It calls for political action at both national and European level, in order to change this dynamic radically, before the European Union is hit by a great depression, whose social and economic costs would be dreadful for all stakeholders across the world.

\section{REFERENCES}

Alesina, A. and S. Ardagna (1998), 'Tales of fiscal adjustment', Economic Policy, 13(27), 487-545. Alesina, A. and S. Ardagna (2010), 'Large changes in fiscal policy: taxes versus spending', in J.R. Brown (ed.), Tax Policy and the Economy, Volume 24, Chicago: National Bureau of Economic Research/University of Chicago Press, pp. 35-68. 
Alesina, A. and R. Perotti (1995), 'Fiscal expansions and fiscal adjustments in OECD countries', Economic Policy, 10(21), 205-248.

Alesina, A. and R. Perotti (1997), 'Fiscal adjustments in OECD countries: composition and macroeconomic effects', International Monetary Fund Staff Papers, 44(2), 210-248.

Artus, P. (2014), 'The conditions for quantitative easing to be effective', Natixis Economic Research Flash, 5 December, available online at http://cib.natixis.com/DocReader/index. aspx?d=496E57587633496E3070592B57326F4D35534F5863773D3D (last accessed on 7 December 2014).

Bagnai, A. (2006), 'Structural breaks and the twin deficits hypothesis', International Economics and Economic Policy, 3(2), 137-155.

Bagnai, A. (2013), 'Unhappy families are all alike: Minskyan cycles, Kaldorian growth, and the Eurozone peripheral crises', A/simmetrie Working Paper, no 1/2013.

Ball, L., D. Furceri, D. Leigh and P. Loungani (2013), 'The distributional effects of fiscal consolidation', International Monetary Fund Working Paper, no WP/13/151.

Barba, A. and G. De Vivo (2013), 'Flawed currency areas and viable currency areas: external imbalances and public finance in the time of the euro', Contributions to Political Economy, 32(1), 73-96.

Bartolini, L. and A. Lahiri (2006), 'Twin deficits, twenty years later', Federal Reserve Bank of New York Current Issues in Economics and Finance, 12(7), 1-7.

Batini, N., G. Callegari and G. Melina (2012), 'Successful austerity in the United States, Europe and Japan', International Monetary Fund Working Paper, no WP/12/190.

Bayoumi, T. and B. Eichengreen (1997), 'Ever closer to heaven? An optimum-currency-area index for European countries', European Economic Review, 41(3), 761-770.

Bibow, J. (2013a), 'The Euroland crisis and Germany's euro trilemma', International Review of Applied Economics, 27(3), 360-385.

Bibow, J. (2013b), 'Lost at sea: the euro needs a Euro Treasury', Levy Economics Institute of Bard College Working Paper, no 780.

Blanchard, O.J. and D. Leigh (2013), 'Growth forecast errors and fiscal multipliers', International Monetary Fund Working Paper, no WP/13/1.

Blanchard, O.J., G. Dell'Ariccia and P. Mauro (2010), 'Rethinking macroeconomic policy', International Monetary Fund Staff Position Note, no SPN/10/03, 12 February.

Brancaccio, E. and M. Passarella (2012), L'Austerità è di Destra e sta Distruggendo l'Europa, Milan: Il Saggiatore.

Cesaratto, S. and A. Stirati (2011), 'Germany and the European and global crises', International Journal of Political Economy, 39(4), 56-87.

Chinn, M.D. and E.S. Prasad (2003), 'Medium-term determinants of current accounts in industrial and developing countries: an empirical exploration', Journal of International Economics, 59(1), 47-76.

Christiano, L.J., M. Eichenbaum and S. Rebelo (2011), 'When is the government spending multiplier large?', Journal of Political Economy, 119(1), 78-121.

Cottarelli, C. and L. Jaramillo (2012), 'Walking hand in hand: fiscal policy and growth in advanced economies', International Monetary Fund Working Paper, no WP/12/137.

Cozzi, T. (2013), 'La crisi e i moltiplicatori fiscali', Moneta e Credito, 66(262), 129-151.

Darvas, Z. (2013), 'The euro area's tightrope walk: debt and competitiveness in Italy and Spain', Bruegel Policy Contribution, no 2013/11.

Draghi, M. (2014), 'Stability and prosperity in monetary union', Speech at the University of Helsinki, 27 November, available online at https://www.ecb.europa.eu/press/key/date/2014/ html/sp141127_1.en.html (last accessed on 6 December 2014).

Eichengreen, B. (1990), 'Costs and benefits of European monetary unification', University of California at Berkeley Department of Economics Working Paper, no 90-150.

Eichengreen, B. and R. Hausmann (1999), 'Exchange rates and financial fragility', Federal Reserve Bank of Kansas City Proceedings, pp. 329-368.

European Central Bank (2012), 'The role of fiscal multipliers in the current consolidation debate', Monthly Bulletin, 14(12), 82-85. 
European Commission (2011), 'Regulation (EU) No. 1176/2011 of the European Parliament and of the Council of 16 November 2011 on the prevention and correction of macroeconomic imbalances', Official Journal of the European Union, L 306, 25-32.

Fisher, I. (1933), 'The debt-deflation theory of great depressions', Econometrica, 1(4), 337-357.

Fleming, J.M. (1971), 'On exchange rate unification', Economic Journal, 8(323), 467-488.

Gambacorta, L. and D. Marques-Ibanez (2011), 'The bank lending channel: lessons from the crisis', Bank for International Settlements Working Paper, no 345.

Giavazzi, F. and M. Pagano (1990), 'Can severe fiscal contractions be expansionary? Tales of two small European countries', in O.J. Blanchard and S. Fischer (eds), NBER Macroeconomics Annual 1990, Volume 5, Boston: MIT Press, pp. 75-122.

Giavazzi, F. and M. Pagano (1996), 'Non-Keynesian effects of fiscal policy changes: international evidence and the Swedish experience', Swedish Economic Policy Review, 3(1), 67-103.

Halevi, J. and Y. Varoufakis (2003), 'The global Minotaur', Monthly Review, 55(3), 57-75.

Hein, E. (2013), 'Finance-dominated capitalism and redistribution of income: a Kaleckian perspective', Levy Economics Institute of Bard College Working Paper, no 746.

Herndon, T., M. Ash and R. Pollin (2014), 'Does high public debt consistently stifle economic growth? A critique of Reinhart and Rogoff', Cambridge Journal of Economics, 38(2), $257-279$.

Huerta de Soto, J. (2012), 'An Austrian defense of the euro', Ludwig von Mises Institute, 22 June, available online at http://mises.org/daily/6069/ (last accessed on 8 December 2013).

International Monetary Fund (2010), 'Will it hurt? Macroeconomic effects of fiscal consolidation', in World Economic Outlook: Recovery, Risk, and Rebalancing, Washington, DC: International Monetary Fund, October, pp. 93-124.

Jenkins, S.P., A. Brandolini, J. Micklewright and B. Nolan (eds) (2012), The Great Recession and the Distribution of Household Income, Oxford and New York: Oxford University Press.

Jordà, Ò., M. Schularick and A. Taylor (2013), 'Sovereigns versus banks: crises, causes and consequences', Federal Reserve Bank of San Francisco Working Paper, no 2013-37.

Juncker, J.-C. (2014), 'Investing in Europe: speech by President Juncker in the European Parliament plenary session on the $€ 315$ billion Investment Plan', Strasbourg: European Parliament, available online at http://europa.eu/rapid/press-release_SPEECH-14-2160_en.htm (last accessed on 6 December 2014).

Kenen, P.B. (1969), 'The theory of optimum currency areas: an eclectic view', in R.A. Mundell and A.K. Swoboda (eds), Monetary Problems of the International Economy, Chicago: University of Chicago Press, pp. 41-60.

Krugman, P. (2011), 'Roubini on internal devaluation', New York Times, 5 November, available online at http://krugman.blogs.nytimes.com/2011/11/05/roubini-on-internal-devaluation/?_ $\mathrm{r}=0$ (last accessed on 8 December 2013).

Lane, P.R. (2012), 'The European sovereign debt crisis', Journal of Economic Perspectives, 26(3), 49-68.

Morselli, A. (2013), 'Deflazione o politiche keynesiane?', Economia e Politica, 10 July, available online at http://www.economiaepolitica.it/index.php/primo-piano/deflazione-opolitiche-keynesiane/ (last accessed on 8 December 2013).

Mundell, R.A. (1961), 'A theory of optimum currency areas', American Economic Review, 51(4), 657-665.

Navicke, J., O. Rastrigina and H. Sutherland (2013), 'Nowcasting indicators of poverty risk in the European Union: a microsimulation approach', EUROMOD Working Paper, no EM11/13.

Nuti, D.M. (2012), 'La strategia di uscita dalla crisi dell'euro', in R. Rossanda and M. Pianta (eds), La Rotta d'Europa: La Politica, Roma: ManifestoLibri, pp. 135-168.

Nuti, D.M. (2013), 'Gli effetti perversi del consolidamento fiscale', Sbilanciamoci, 11 October, available online at http://www.sbilanciamoci.info/Sezioni/globi/Gli-effetti-perversidel-consolidamento-fiscale-20423 (last accessed on 8 December 2013). 
Rossi, S. (2007), 'International capital flows within the European Monetary Union: increasing economic divergence between the centre and the periphery', Intervention: European Journal of Economics and Economic Policies, 4(2), 309-329.

Rossi, S. (2012), 'Replacing recession and austerity with growth and solidarity across Euroland', in M. Méaulle (ed.), Austerity is Not the Solution! Contributions to European Economic Policy, Brussels: Foundation for European Progressive Studies, pp. 33-40.

Rossi, S. (2013), 'Financialization and monetary union in Europe: the monetary-structural causes of the euro-area crisis', Cambridge Journal of Regions, Economy and Society, 6(3), $381-400$.

Rossi, S. (2015), 'The euro-area crisis: structural origins and possible exit strategies', in A. Bitzenis, N. Karagiannis and J. Marangos (eds), Europe in Crisis: Problems, Challenges, and Alternative Perspectives, Basingstoke, UK and New York: Palgrave Macmillan, pp. 143-154.

Rossi, S. and B. Dafflon (2012), 'Repairing the original sin of the European Monetary Union', International Journal of Monetary Economics and Finance, 5(2), 102-123.

Sala-i-Martín, X. and J. Sachs (1992), 'Fiscal federalism and optimum currency areas: evidence for Europe from the United States', in M. Canzoneri, V. Grilli and P.R. Masson (eds), Establishing a Central Bank: Issues in Europe and Lessons from the US, Cambridge, UK: Cambridge University Press, pp. 195-219.

US Department of the Treasury (2013), 'Report to Congress on International Economic and Exchange Rate Policies', Washington, DC: US Department of the Treasury, 30 October, available online at http://www.treasury.gov/resource-center/international/exchange-rate-policies/ Documents/2013-10-30_FULL\%20FX\%20REPORT_FINAL.pdf (last accessed on 8 December 2013).

Vernengo, M. and E. Pérez-Caldentey (2012), 'The euro imbalances and financial deregulation: a post Keynesian interpretation of the European debt crisis', Real-World Economics Review, $59,83-104$.

Watt, A. (2013), 'The German minimum wage debate: lessons from an EU comparison', Social Europe Journal, 23 October, available online at http://www.social-europe.eu/ 2013/10/the-german-minimum-wage-debate-lessons-from-an-eu-comparison/ (last accessed on 8 December 2013). 